\title{
Impact of the Aral Sea Syndrome - the Aralkum as a Man-Made Dust Source
}

\author{
Christian Opp ${ }^{1, *}$, Michael Groll ${ }^{1}$, Oleg Semenov ${ }^{2}$, Natalya Vereshagina $^{3}$, and Asia Khamzina ${ }^{4}$ \\ ${ }^{1}$ University of Marburg, Department of Geography, 35037 Marburg, Germany \\ ${ }^{2}$ Kazakh Research Institute for Ecology and Climate, 480072 Almaty, Kazakhstan \\ ${ }^{3}$ UZHYDROMET, Hydrometeorological Research Institute (NIGMI), 100052 Tashkent, Uzbekistan \\ ${ }^{4}$ Korea University, Division of Environmental Science and Ecological Engineering, 02841 Seoul, South Korea
}

\begin{abstract}
Ground based dust monitoring is an important tool for the long-term monitoring of aeolian sediment transport in Central Asia as it provides valuable insights into the spatial and temporal dynamics of dust deposition as well as grants access to the transported material for further analyses. Between 2006 and 2012 such a monitoring was carried out in the Turan lowland to analyze the effects of the newly formed Aralkum. The detected spatial and temporal dust deposition variability was significant and encourages further studies. The dust deposition increased over time, which correlates with a decreasing trend in precipitation, increasing wind speeds and a shift towards northern winds. More than $50 \%$ of all dust samples collected exceed the health based deposition threshold and the most intense dust storm events reached ground level deposition rates of up to $150 \mathrm{~g} / \mathrm{m}^{2}$ per hour. This study showed the impact of the Aralkum, but also that the Kyzylkum is a far more active dust source. With regard to climate change and an increasing aridity in the region it can be expected that the aeolian dust transport will continue to increase, making a wide-spread monitoring program even more important.
\end{abstract}

\section{Introduction and Study Design}

Central Asia is a landlocked region characterized by an arid climate and wide-spread deserts and semi-deserts, especially in the lower parts of the Aral Sea basin, mainly the Turan lowland. Common aeolian processes in this region are the transport of dust and sand across long distances from the various source regions to densely populated oases and urban areas. The Kyzylkum and the Karakum are the two largest deserts in the Turan lowland and important dust sources in the region and beyond. Due to the overexploitation of the Central Asian water resources [1], the Aral Sea, once the fourth largest inland lake worldwide, has been transformed into a salty desert - the Aralkum - which, with an area of more than $60,000 \mathrm{~km}^{2}$ has become a major source for the aeolian transport of lake bed sediments [2-4]. The negative impacts of this manmade desert on the surrounding region have been widely debated and satellite images impressively show the white plumes of salty dust blown from the Aralkum into the Turan lowland [5]. But even though the Aral Sea syndrome and the dramatic satellite images have been in the spotlight of the scientific and public discussion for years, only few projects have analyzed the aeolian sediment transport in detail [6]. The size of the affected area ( 1.5 million $\mathrm{km}^{2}$ spread out across three countries) and its remoteness means that most studies focused on remote sensing as their primary data for the dust monitoring. This has lead to a lack of continuous ground data for a long-term evaluation of the impact the Aralkum has on the region as well as for the analysis of the spatial and temporal patterns of the sediment transport and their connection to meteorological and climatic factors.

Carrying out such a ground-based monitoring in the Aral Sea basin was the central aim of the EU-CALTER project [7] and in combination with two other projects (the UNESCO KHOREZM project [8] and the LUCA project [9]) the field measurements included a total of 23 meteorological stations in Kazakhstan, Turkmenistan and Uzbekistan (Fig. 1). 
Dust samples were collected and weighted on a monthly basis in $3 \mathrm{~m}$ height using inverted Frisbee passive deposition samplers which have been used successfully in Central Asia for decades [10-13]. This extensive set of monthly deposition data (2006-2012) was complemented by samplers of the same design, which were only exposed during dust storm events (defined by a visibility of less than $1 \mathrm{~km}$ ). The same 23 meteorological stations were also used for the collection of meteorological data (air temperature, precipitation, wind speed, and direction). Based on their spatial connection the 23 stations were clustered into regions (Aralkum, Kyzylkum, Karakum, Khorezm, and others, Fig. 1) to analyze the meteorological and deposition characteristics as well as their spatial and temporal dynamics. $\left(-3.6^{\circ} \mathrm{C}\right.$; January average of $\left.-7.1^{\circ} \mathrm{C}\right)$ and no significant temperature trends have been observed during the study period.

The average precipitation in the Turan lowland was $82.1 \mathrm{~mm}$ per year, with a maximum during winter and spring $(9.4 \mathrm{~mm}$ per month and $8.8 \mathrm{~mm}$ per month, respectively). The months with the highest average precipitation were March $(10.7 \mathrm{~mm})$ and November $(9.9 \mathrm{~mm})$. Summer is a particularly dry season in the Turan lowland with just $3.1 \mathrm{~mm}$ per month. During the study period a considerable decrease of the annual precipitation (from $109.3 \mathrm{~mm}$ to $66.5 \mathrm{~mm}$ ) has been recorded. The rainfall distribution showed also a strong spatial component which ranged from $66 \mathrm{~mm}$ to $105 \mathrm{~mm}$ (for the stations Muynak and Jaslyk, both

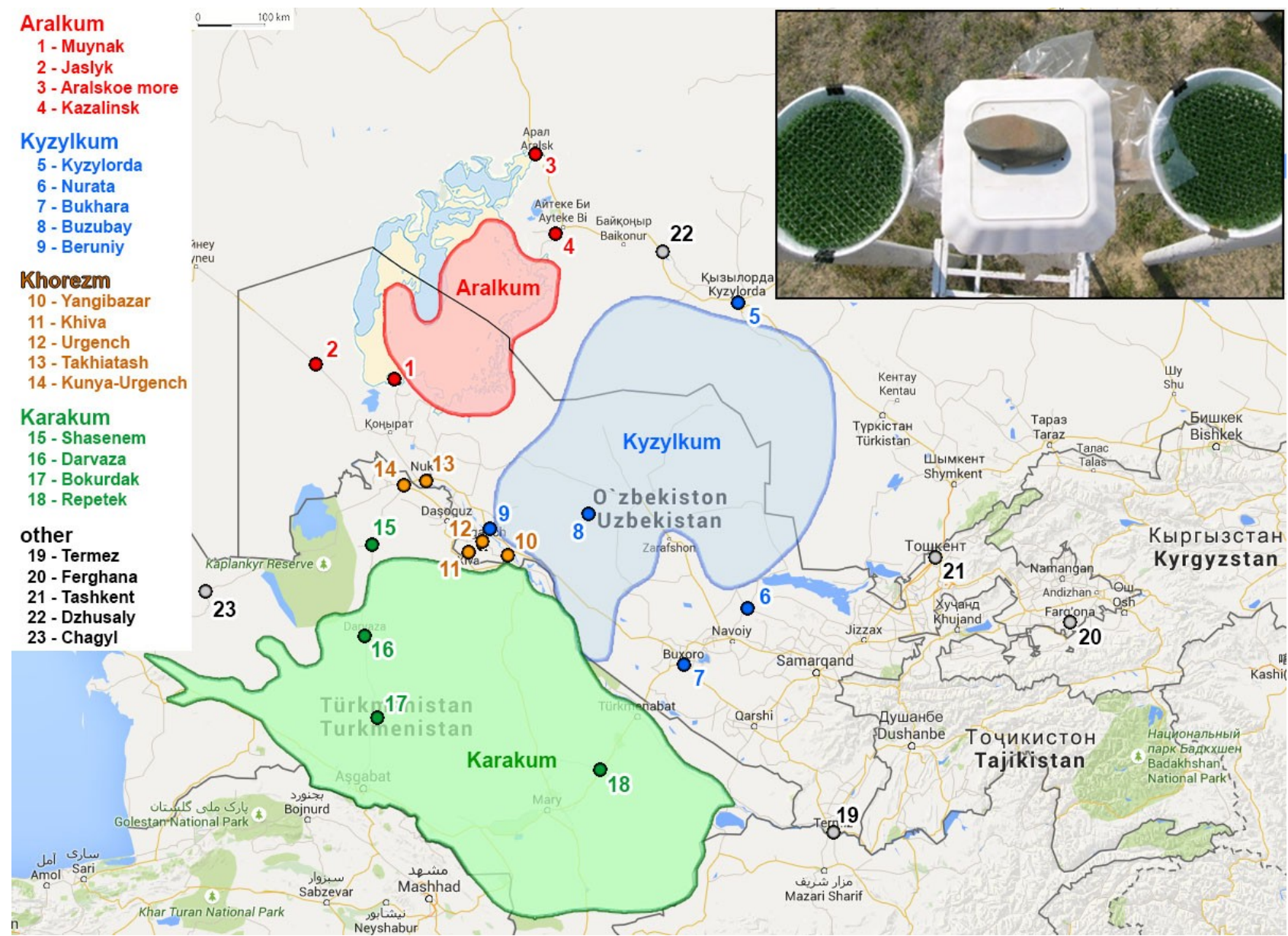

Fig. 1. Dust sampling stations and their regional grouping.

\section{Results}

\subsection{Meteorological characterization of the study area}

The average air temperature across all stations was $13.9^{\circ} \mathrm{C}$ between 2006 and 2012. The Kyzylkum region was characterized by with highest average temperature (regional average of $15.0{ }^{\circ} \mathrm{C} ; 16.2{ }^{\circ} \mathrm{C}$ at the station Beruniy), while the Aralkum had the lowest average temperature (regional average of $11.9{ }^{\circ} \mathrm{C} ; 11.3{ }^{\circ} \mathrm{C}$ at Jaslyk). The climate is continental with hot summers $\left(28.2^{\circ} \mathrm{C}\right.$; July average of $\left.29.0^{\circ} \mathrm{C}\right)$ and cold winters within the Aralkum region). Overall the Kyzylkum region was - at least during the study period characterized by a higher precipitation than even the non-desert region Khorezm (94.1 $\mathrm{mm}$ to $79.8 \mathrm{~mm}$ ).

The wind speed data recorded at the meteorological stations showed a wide spread from an average of $0.6 \mathrm{~m} / \mathrm{s}$ in Yangibazar (Khorezm) to and average of $8.2 \mathrm{~m} / \mathrm{s}$ in Buzubay (Kyzylkum). The overall average wind speed was $3.2 \mathrm{~m} / \mathrm{s}$ and showed a low intraannual variability (from $2.2 \mathrm{~m} / \mathrm{s}$ in October to $4.4 \mathrm{~m} / \mathrm{s}$ in February and June). The interannual dynamic, on the other hand, was considerable and ranged from $0.5 \mathrm{~m} / \mathrm{s}$ in 2005 to $4.2 \mathrm{~m} / \mathrm{s}$ in 2009 with a general trend of increasing wind speeds. Sand storms with a duration of 17, 19, and 26 hours, observed within 1984 field campaigns near the eastern banks of the Aral Sea, 
reached an average windspeed of $16-21 \mathrm{~m} / \mathrm{s}$ with peaks up to $25 \mathrm{~m} / \mathrm{s}$ during the summer months [3].

Across all stations and years $39.9 \%$ of all months were dominated by winds from eastern directions, followed by southern and northern winds $(30.5 \%$ and $27.2 \%$, respectively). Winds from western directions only occurred during $2.3 \%$ of all recorded months. But individual regions within the Turan lowland deviated from this average to a degree: In the Karakum and Aralkum eastern winds were especially dominant $(73.3 \%$ and $68.8 \%$ ) while southern winds were not/hardly detected $(0 \%$ in the Karakum and $2.1 \%$ in the Aralkum). In Khorezm, on the other hand, eastern winds were recorded less frequently than southern winds $(24.4 \%$ to $50.0 \%$ ) and in the Kyzylkum winds from northern directions dominated $(62.2 \%)$. Throughout the year the dominant wind direction at the meteorological stations shifted, following an undulating pattern. Southern winds were strongest during winter and autumn while northern winds were most frequent during winter and summer. Eastern winds dominated during spring and summer and western winds were detected to infrequently for any pattern. The wind direction dominance pattern also changes over the whole time of this study. From 2006 to 2008 southern winds were considerably more frequent than in the following years, while the reverse is true for winds from northern directions. This might indicate a larger temporal pattern or effects of global climate changes.

\subsection{Dust deposition dynamics}

The average dust deposition in the Turan lowland for the period 2006-2012 and across all stations was $117.2 \mathrm{~kg} / \mathrm{ha}$ *month $\left(11.7 \mathrm{~g} / \mathrm{m}^{2}\right.$ per month). The highest deposition intensity was detected in the Kyzylkum region $\left(247.7 \mathrm{~kg} / \mathrm{ha}{ }^{*}\right.$ month). $52 \%$ of all samples collected there exceeded the long-term dust deposition threshold of $10.5 \mathrm{~g} / \mathrm{m}^{2}$ per month (Tab. 1), a value related to respiratory diseases and based on clinical research [14]. The man-made Aralkum ranked second with an average deposition intensity of $151.5 \mathrm{~kg} / \mathrm{ha}$ *month and $45 \%$ of all samples exceeding the health threshold. The Karakum, the largest desert in the Aral Sea basin, was characterized by a deposition rate of $125.2 \mathrm{~kg} / \mathrm{ha} *$ month. But even though it seems as if the Karakum poses a smaller health risk due to its lower average dust deposition rate and threshold excess $(40.5 \%)$, the percentage of samples (months) with low or very low dust deposition intensity $(<25$ and $<10 \mathrm{~kg} / \mathrm{ha}^{*}$ month, respectively) was much lower in that region than in any other region analyzed in this study (Tab. 1). Khorezm was included as a separate region in this study as it is not a dedicated dust source but a densely populated important agricultural center in the lower Amu-Darya river basin. Due to its location between the three major deserts in the Turan lowland Khorezm is especially prone to the impacts of aeolian dust. This region showed the lowest deposition intensity $\left(60.9 \mathrm{~kg} / \mathrm{ha}^{*}\right.$ month or $6.1 \mathrm{~g} / \mathrm{m}^{2 *}$ month $)$ in the area around the Aral Sea, but even here more than one fifth of all sampled months (21.3\%) had to be considered potentially harmful for the respiratorial system (Tab. 1). Comparing these four regions within the Turan lowland with the "other" meteorological stations included in this study (e.g. Tashkent or Ferghana, Fig. 1) shows that the aeolian dust processes are concentrated on the arid Central Asian lowlands. Stations closer to the mountainous eastern parts of Central Asia and those further away from the major dust sources showed much smaller dust deposition rates and only $3 \%$ of all samples from these other parts of the Aral Sea basin exceeded the health based deposition threshold (Tab. 1).

The analysis of the temporal dynamic showed that the dust deposition rate was higher during fall and spring (122.4 kg/ha*month and $115.1 \mathrm{~kg} / \mathrm{ha} *$ month, respectively) and slightly lower during summer and winter $(108.7 \mathrm{~kg} / \mathrm{ha} *$ month and $110.3 \mathrm{~kg} / \mathrm{ha} *$ month, respectively). The health threshold excess, however, was also increased during the winter months $(37 \%$ in winter and spring, compared to $27 \%$ in summer and fall). This shows that even though the dust deposition follows seasonal patterns the aeolian sediment transport is an important problem throughout the year. The overall intensity of the dust transport increased between 2006 and 2012 which is closely related to the decrease of precipitation, the increase of the wind speed, and potentially the shift to northern wind directions.

Table 1. Dust deposition characteristics.

\begin{tabular}{|c|c|c|c|c|c|}
\hline \multirow[b]{2}{*}{$\begin{array}{l}\text { Dust data } \\
\text { (without dust } \\
\text { storms) }\end{array}$} & \multicolumn{5}{|c|}{ Region } \\
\hline & $\underset{\Xi}{E}$ & 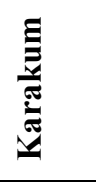 & 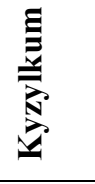 & 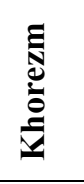 & 爮 \\
\hline $\begin{array}{l}\text { Avg. Dust } \\
\text { Deposition } \\
\text { (kg/ha*month) }\end{array}$ & 151.5 & 125.2 & 247.7 & 60.9 & 24.5 \\
\hline $\begin{array}{l}\% \text { of samples } \\
\text { exceeding the } \\
\text { health threshold }\end{array}$ & 45.0 & 40.5 & 52.0 & 21.3 & 3.0 \\
\hline $\begin{array}{l}\% \text { of samples } \\
\text { with } \\
<25 \mathrm{~kg} / \mathrm{ha}^{*} \text { month }\end{array}$ & 26.7 & 10.8 & 21.4 & 46.1 & 87.9 \\
\hline $\begin{array}{l}\% \text { of samples } \\
\text { with } \\
<10 \mathrm{~kg} / \mathrm{ha}^{*} \text { month }\end{array}$ & 10.8 & 0.0 & 15.3 & 25.7 & 60.6 \\
\hline
\end{tabular}

A total of 40 dust storm events have been recorded within the sampling period 2006-2012. A quarter of these events were registered in 2009, which was the year with the highest average wind speed $(4.2 \mathrm{~m} / \mathrm{s})$. In September of that year the most intense dust storm was recorded in Buzubay (Kyzylkum), with an hourly deposition intensity in $3 \mathrm{~m}$ height of $13.4 \mathrm{~g} / \mathrm{m}^{2}$, which equals approximately $150 \mathrm{~g} / \mathrm{m}^{2}$ per hour close to the ground surface [15]. There occurrence of dust storms is closely related to the average wind speed as well as to the precipitation, but shows no correlation to the air temperature. The majority of dust storm events were 
connected to winds from south-eastern directions (ESESSE: $47.3 \%$ of all dust storms), but most of the dust storm deposition occurred during events with northern winds (NNW-NNE: $62.3 \%$ of the deposited material). These results show the wide spread and variability of meteorological parameters within the Turan lowland and the even greater spatial and temporal dynamic of the deposition intensity of aeolian dust. The Aralkum has emerged as the third large dust source in the region, but especially the Kyzylkum is of a far greater importance for the regional dust regime. The detected temporal trends in the precipitation, wind speed, wind direction and dust deposition show that the system is highly dynamic and currently changing. Whether these changes are cyclic and just part of a larger spatio-temporal pattern or if they are the effects of a man-made climate change cannot be assessed based on the limited data base available. It is recommended to utilize ground-based dust monitoring as an easy and effective tool for a long-term monitoring which complements remote sensing methods very well.

\section{References}

1. M. Groll, C. Opp, R. Kulmatov, M. Ikramova, I. Normatov, Environmental Earth Sciences, 73, 743763, DOI: 10.1007/s12665-013-2988-5 (2015)

2. C. Opp. Geographische Rundschau International Edition, 1,2, 12-20 (2005)

3. O.E. Semenov. Introduction into the experimental meteorology and climatology of sand storms. Almaty (2011)

4. P. Micklin, Environmental Earth Sciences, 75, 844, 15 (2016)

5. L. Spivak, A. Terekhov, I. Vitkovskaya, M. Batyrbayeva, Curr. Prob. Remote Sens. Earth Space, 2, 6, 193-202 (2009)

6. H.K. Kim, C.-U. Ro. In: S. Brstilo, Q. Madunic (eds) Dust Storms. Elemental Composition, Causes and Environmental Impacts. Natural Disaster Research, Prediction and Mitigation Series. New York (2010)

7. M. Groll, C. Opp, I. Aslanov, Aeolian Research, 9, 49-62 (2013)

A. Khamzina, J.P.A. Lamers, P.L.G. Vlek, In: C. Martius, I. Rudenko, J.P.A. Lamers, P.L.G. Vlek (eds) Cotton, Water, Salts and Soums, Springer (2012)

B. Opp, M. Groll, I. Aslanov, T. Lotz, N. Vereshagina, Quaternary International, 429, 86-99, DOI: 10.1016/j.quaint.2015.12.103 (2017)
8. S.L. O’Hara, G.F.S. Wiggs, B. Mamedov, G. Davidson, R.B. Hubbard, The Lancet, 355, 627-628 (2000)

9. L. Orlovsky, G. Tolkacheva, N. Orlovsky, B. Mamedov, In: Brebbia, C.A. (ed). Air Pollution, XII, 353-362 (2004)

10. G.A. Tolkacheva, SANIGMI report (2000) (in Russian)

11. G.F.S. Wiggs, S. O’Hara, J. Wegerdt, J. van der Meer, I. Small, R. Hubbard, The Geographic Journal, 169, 142-157 (2003)

12. Bundesministerium für Umwelt, Naturschutz und Reaktorsicherheit, Gemeinsames Ministerialblatt vom 30. Juli 2002, 25-29, 511-605 (2002) (in German)

13. M. Groll, C. Opp, O. Semenov, A. Shapov, In: Müller L et al. (eds) Novel Methods and Results of Landscape Research in Europe, Central Asia and Siberia - Vol. II: Understanding and Monitoring Processes in Soils and Water Bodies, 265-269, DOI: 10.25680/6865.2018.94.78.154 (2018) 